\title{
IUGS Executive Committee meets
}

\author{
Florence, Italy, January 26-31, 1999
}

Florence, Italy, was the venue of the 45th meeting of the IUGS Executive Committee (EC), January 26-31, 1999. Florence was chosen because it is a potential site for the 32nd International Geological Congress in 2004, as is Vienna, the venue of last year's EC meeting. Convening the EC in each potential venue provided opportunties to contrast the meeting facilities available in each place and the potential for field trips to important sites bearing on topical issues in modern geology. The formal meeting was preceded by a stimulating scientific program on January 22 (see below) and a fascinating 3-day field excursion to view notable Italian geologic and archeological sites. Meeting arrangements were planned and coordinated by the IUGS Secretary General, Prof. Attilio Boriani, and Prof. Evi Giobbi, both of the University of Milano. Generous financial support for lodging, meals, meeting facilities, and other amenities for participants was provided by the Italian Department of Civil Protection (Prof. Franco Barberi), the Italian National Research Council (Prof. Piero Manetti), the Universities of Florenze and Milano, and by Newtours s.r.l.

Following welcoming addresses by Prof. Piero Manetti, of the University of Florence, and Marco Amanti, of the Italian Geological Survey, IUGS President Robin Brett led the Executive Committee through the very full agenda that characterizes these annual meetings.

Major activities of the EC meeting included:

- receiving reports on IUGS administrative and financial matters:

- reviewing annual reports and future plans of IUGS scientific bodies;

- receiving reports on cooperative enterprises;

- considering IUGS policy and strategic matters; and

- recommending 1999 budget allocations for IUGS activities.

Especially notable was the fact that this was the first meeting of the IUGS Executive Committee to bring together the Presidents of ICSU's three Earth Science Unions: the International Union of Geological Sciences (IUGS), the International Union of Geodesy and Geophysics (IUGG), and the International Geographical Union (IGU). The three Presidents felt strongly that fostering closer cooperation between the three Unions will strengthen the position of the Earth Sciences within ICSU.

Selected Actions Arising from the Agenda

- Approved Namibia and Gambia as new member countries, pending final decision of the IUGS Council in 2000.
- Planned further an initiative to formulate a comprehensive strategic plan to guide the Union in light of the profound changes that have occurred over the past few years in the funding environment for geoscience research and in the social, political and scientific infrastructure in which the IUGS operates. It was hoped that a formal meeting of the Strategic Planning Group could be arranged in Strasbourg, France, prior to the EUG meeting that begins there on March 28.

- Scheduled for Strasbourg, France, prior to the EUG meeting, a meeting of an ad hoc Advisory Board for Research Development to review the work progress and direction of three IUGS Scientific Commissions: the Commission on the Management and Application of Geoscience Information (COGEOINFO), the Commission on Geological Sciences for Environmental Planning (COGEOENVIRONMENT), and the Commission on Global Sedimentary Geology (CGSG).

- Decided to lower from US\$100 to US\$50 the annual membership fee for Associate Members in Category D. This category applies to individuals with IUGS-related interests.

- Agreed to publish a new edition of the Global Stratigraphic Chart. The first Global Stratigraphic Chart was published in 1989 for the 28th IGC. Since then, fourteen new boundary definitions have been voted upon by the ICS and ratified by IUGS; several new stage names have also been introduced. The new version will give a clear picture of the state of the art in international chronostratigraphic nomenclature.

- Addressed the demand by some Quaternary stratigraphers to lower the Plio-Pleistocene Boundary, formally defined by a GSSP at Vrica in 1984. The Bureau of the IUGS International Commission on Stratigraphy (ICS) had asked the IUGS to approve the result of a joint vote of the Subcommission on Quaternary Stratigraphy and the Subcommission on Neogene Stratigraphy. Both Subcommissions voted to reject the demand to lower the PlioPleistocene boundary. The EC strongly approved the Subcommissions' vote, which supported the existing boundary.

Held in conjunction with the EC meeting were meetings of the Advisory Board on Publications (ABP). Following the meetings, the ABP Chairman, Prof. Glen Caldwell, reported to the Executive Committee on the important matters and issues considered by the Board. These included:

- several matters related to Episodes:
- possibilities for collaborative publication of non-serial IUGS publications; What is IUGS?;

- new considerations for publishing an abridged version of the International Stratigraphic Guide ( 2nd ed);

- issues related to publishing a new International Correlation Chart; and

- the IUGS web site.

This meeting included a visit to view the facilities of the Congress Centre of Fortezza da Basso, where the 32nd International Geological Congress would be held in 2004 if Florence is chosen as the venue. This complemented a similar visit to the Vienna Congress Centre made last year. The final decision on the site of the 32nd IGC will be made by the Council of the 31 st IGC in Rio de Janiero, Brazil, in 2000.

The official minutes of this EC meeting (provisional until approved by the Executive Committee at its meeting in 2000) will be available on this web site in a few weeks. Printed copies will be available from the IUGS Permanent Secretariat in Trondheim, Norway.

If Italy were to be chosen as the site for the 32nd IGC, the Italian National Committee for IUGS has suggested in an Interim Report that the conceptual framework of the Congress should be developing a consistent theoretical basis for the prediction and managememt of the global challenges to the international geological community in the third millenium. In keeping with this, the proposed theme of the Congress is, Geology, Natural Hazards, Sustainable Development, and Cultural Heritage in the Mediterranean Area: A Global Perspective. Many technical sessions and field trips would be organized to demonstrate and explore what needs to be done. As part of the EC meeting, therefore, our Italian hosts sought to add substance to their proposal in both theoretical and practical ways. Prior to the formal meeting of the Executive Committee, a Workshop entitled Geosciences: Risk Assessment and Reduction and a Panel Discussion entitled Geosciences and Society were held at the Centro Protezione Civile di Castelnuovo di Porto, near Rome. The Workshop was convened by Prof. Franco Barberi, State DeputySecretary of Civil Protection, organized and co-convened by Prof. Forese C. Wezel, President of the Preparatory Committee for the 32nd IGC, and focused attention on the significant geologic hazards of Italy, some of which (seismic and hydrogeologic) have even within the past two years caused many deaths and severe damage to property, including priceless works of art. The Panel Discussion was chaired by Prof. Umberto Cordani, Chairman of Organizing Committee of the 31st International Geological Congress and former IUGS President, and featured short presentations by members of the IUGS Executive Committee and the IUGS "extended family," who related a variety of interesting perspectives and experiences in 
applying geosciences to societal problems and needs.

Following the full day devoted to the workshop and panel discussion, the group enjoyed a 3-day field excursion to view geologic features and examples of the effects of geologic processes and hazards in Italy, guided by scientists and other experts intimately familiar with the features visited. Included were Naples and Mt. Vesuvius; the May 1998 debris flows in the Sarno region east of Naples; the ancient city of Pompei, south of Naples, which was buried in 79 A.D. by an eruption of Vesuvius; the urban geology of Rome, especially the damaging effects of the interaction of subsurface geology and historic seismicity on important monuments of Imperial Age (the Colosseum and the honorary columns of Traianus and Marcus Aurelius); and the historic Basilica of St. Francis at Assisi, which was heavily damaged by a severe earthquake in 1997 .

Members of the EC agreed unanimously that the practical demonstration of these natural disasters enhanced immeasurably their understanding of the past, and potentially future, impact of such events on society; the magnitude of this problem in densely populated regions, and on the huge number of historic sites and monuments in Italy that must be preserved at staggering cost; and on the appropriateness of giving considerable emphasis to this aspect of 'geoscience and society' in any future IGC that may be held in Italy or surrounding parts of the Mediterranean region.

John Aaron

IUGS Webmaster

\section{International}

workshop on

ultrahigh-pressure

metamorphism and exhumation

\author{
Stanford, USA \\ December 4-6, 1998
}

The task group "Ultrahigh-Pressure Metamorphism and Geodynamics in Collisiontype Orogenic Belts" was established in 1993 as Project III-6 of the International Lithosphere Program (ILP). Since then, study of ultrahigh-pressure (UHP) metamorphic rocks in terms of their genesis and exhumation, and implications for the role of fluid in geochemical cycling and descending slab/mantle wedge interactions have attracted continuous international attention.
Recently funded continental drilling in the Sulu UHP terrane of eastern China and a new Japanese mapping project involving the diamondiferous Kokchetav terrane of northern Kazakhstan are just two examples of this heightened scientific interest. Through the support of the International Lithosphere Project, Task Group III-6 members have made significant contributions to the study of several UHP terranes.

An international workshop on ultrahigh-pressure metamorphism and exhumation at Stanford represents an official annual event of ILP Task Group III-6 and was the fifth workshop for this project. The first one was held at Stanford in 1994, the second one at Heifei in the Dabie Mountains in 1995, the third one at Beijing in 1996, and the fourth one at Ascona, central Swiss Alps in 1997. The fifth workshop was organized by J. G. Liou and W. G. Ernst of Stanford, Bolin Cong of Chinese Academy of Sciences, and Shige Maruyama of Tokyo Institute of Technology. The meeting was supported by the National Science Foundation, the Stanford Department of Geological \& Environmental Sciences, the Stanford School of Earth Sciences, the Stanford China Industrial Affiliates Programs, and ILP Task Group III-6. The two and half-day workshop covered four major themes with 5 different sessions:

1. Petrogenesis and tectonics of UHP terranes in east-central China,

2. Petrogenesis and tectonics of the Kokchetav Massif, northern Kazakhstan, and West Gneiss Region, central Norway,

3. Study of UHP garnet peridotites as a new window into mantle processes, and

4. Petrogeneses and exhumation of UHP eclogites and the enclosing gneisses.

Many exciting findings and research projects were described by participants at this workshop. These include: (1) the first Chinese Continental Drilling Project in the Sulu UHP terrane by Xu, Z. and Yang, W. of the Chinese Academy of Geological Sciences; (2) new mapping results of the Kokchetav Massif by Japanese colleagues, led by Shige Maruyama; (3) the occurrence of majoritic garnet in garnet peridotites from the Western Gneiss Region independently by van Roermund of the Netherlands and Peter Robinson of USA; (4) the discoveries of high-P clinoenstatite from the Alpe Arami lherzolite body by Green et al. of USA and from the Sulu garnet pyroxenites drill-hole core of China by Zhang et al. of Stanford; and (5) rapid exhumation of UHP slices by many participants from petrological, geochronological and modeling results.

More than 80 papers were presented in four oral sessions and one poster session. Extended abstracts are included in a 250page abstract volume. Four special issues for the above four themes will be prepared and published in Continental Dynamics $\left({ }^{\#} 1\right)$, the Island Arc (\#2), Journal of Metamorphic Geology (\#3), and Lithos. (\#4). In addition, a final report for ILP Task Group III-6 on UHP Metamorphism and Geotectonics, will be published in International Geology Review during 1999.

Prior to the workshop, the first committee meeting of the Chinese Continental Scientific Drilling Project was held on December 3, 1998 at Stanford. The meeting was organized by the P.I. (Xu, Zhiqin of CAGS); other participants include 8 Co-P.Is for the drilling project, NSF EAR director (Ian McGregor), ICDP secretary (Joern Lauterjung), and several other guests. It was decided that the second committee meeting will be held in Beijing on August 5 and 6, 1999.

A one-hour Task Group Committee meeting was held at Stanford on December 5th and conveyed by Secretary Cong Bolin. It was attended by most committee members attending the workshop. Nick Sobolev described the two-part plan for the Fourth International Field Eclogite Conference to be held in the Maksyutov Complex of the South Urals and the Kokchetav Massif of northern Kazakhstan, August 9 to 19, 1999. Secretary Cong reported that $\$ 1,000$ will be provided by Task Group III-6 for this field eclogite conference. It was suggested that the planned field eclogite conference could be too long and too expensive for some participants, and recommended to have an option for two independent but continuos field conferences - one for the Maksyutov Complex and the other for the Kokchetav Massif. Wang, Q. reported the justification for a renewal proposal for the TASK Group III-6 to be submitted to ILP for approval in 1999. Liou and Ernst described an outline and plan for the final Task Group Report to be published in International Geology Review.

More than 95 participants (26 Chinese, 25 American, 18 Japanese, 7 German, 4 French, 4 Canadian, 3 English, 3 Swiss, 2 Kazakhstan, 2 Russian, 2 Belgian, 1 Norwegian, 1 Netherlandish, and 1 Romanian) attended the Stanford Workshop. It was followed by AGU Special Session on UHP Metamorphism and Geodynamics in Collision-Type Orogenic Belts at San Francisco on December 8-9, 1998. Most of the participants for the workshop also attended and presented papers in the two oral sessions and one poster session. In total, 38 abstracts are included in AGU EOS, vol. 79, no. 45.

The Stanford workshop served to expedite: (1) scientific exchanges among geoscientists from various countries through oral and poster presentations, informal discussions, and optical examination of new findings of ultradeep minerals; (2) committee meetings for the Deep Drilling Project in China; (3) Task Group III-6 future plans; (4) proposed trenching of the Kokchetav Massif; and (5) scientific publication of high-quality special issues in timely fashion.

\section{J. G. Liou and W. G. Ernst}

Department of Geological and Environmental Sciences, Stanford University, Stanford, CA 94305, USA 


\section{International workshop on Cretaceous- Paleogene transitions in Tunisia: The El Kef stratotype for the Cretaceous- Paleogene boundary reconfirmed}

\author{
Tunis, Tunisia, May 12-16, 1998
}

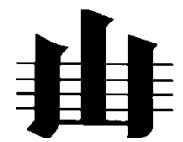

The Cretaceous-Paleogene boundary (traditionally abbreviated "K/T boundary") was formally defined by a Global Standard Stratotype-section and Point (GSSP) near the locality of El Kef, Tunisia, in 1991. Unlike all other GSSPs ratified prior to 1996, the El Kef GSSP has never been published in Episodes. Nevertheless, its status as a mandatory GSSP is perfectly valid as it was duly voted upon by the Full Commission of the ICS (International Commission on Stratigraphy) and ratified by IUGS. However, in recent years the Chairman of ICS (JR) received various critical comments concerning difficulties in finding the exact location of the type-section and the unsatisfactory preservation of the site itself. If true, this might eventually lead to the abolishment of the El Kef GSSP and its replacement by another more appropriate type-section. Before taking such action into consideration, ICS representatives and a host of interested scientists from the international community revisited El Kef and critically examined the original type section taking into account the scientific as well as regional paleogeographic contexts.

For this purpose the International workshop on Cretaceous-Paleogene transitions in Tunisia was held in May 1998, co-sponsored by ICS (J. Remane, Chairman) and the Geological Survey of Tunisia (M. Ben Haj Ali, Director). The workshop and subsequent field trip were a resounding success thanks to the excellent cooperation, organizational skills, and gracious hospitality of scientists at the Tunisian Geological Survey and the Geology Department at Tunis University. We take this opportunity to express our heartfelt gratitude to the entire Tunisian team and especially the Director, Dr. M. Ben Haj Ali, as well as Dr. H. Bensalem, who have worked tirelessly to make this meeting a great success. The workshop and meeting were attended by nearly 40 stratigraphers from 8 countries. Representatives of ICS included J. Remane, Chairman, and by J. Hardenbol, Vice-chairman of the Paleogene Subcommission of ICS. The scientific organization was prepared by G. Keller who was a member of the International Working Group that originally established the El Kef GSSP.

The workshop started on May 13, 1998, with a scientific session where 22 papers concerning various aspects of the "K/T boundary" were presented and complemented by 18 posters. These oral presentations and posters confirmed the unique possibilities offered by the Tunisian sections for studying the "K/T boundary" interval. The high sedimentation rates provide for an extended documentation without discernable gaps at El Kef and only small gaps in the Elles and Aïn Settara sections. Other important strong points are the richness in microand nannoplankton and the total absence of metamorphism, which make detailed faunal, geochemical and mineralogical analyses feasible. These facts were confirmed by the three-day field trip following the meeting at Tunis, with El Kef visited on May 14, Aïn Settara on May 15, and Elles on May 16 (Figure 1). These three sections occupy different positions on a paleogeographical transect from upper slope (El Kef) to middle and outer shelf environments (Aïn Settara, Elles).

The field trip and biostratigraphic investigations confirmed that the El Kef section has the most expanded and continuous sedimentation record of the Tunisian sections as well as worldwide to date. The Elles and Aïn Settara sections, which are located $50 \mathrm{~km}$ southeast and $75 \mathrm{~km}$ southwest respectively, have nearly equally expanded sedimentation records for the "K/T boundary" and early Danian. Similar to El Kef, they contain a $50-60 \mathrm{~cm}$ thick clay layer with a $2-4 \mathrm{~mm}$ thick red layer at its base with spherules, Nirich spinels, the Ir anomaly and the mass extinction of tropical and subtropical foraminiferal species. But unlike at El Kef, just below the K/T boundary clay layer, these two sections contain a $5 \mathrm{~cm}$ to $25 \mathrm{~cm}$ thick bioclastic layer overlying an undulating erosional surface. This indicates that a minor hiatus may be present near the top of the Maastrichtian in these sections. The duration of this hiatus is unknown, but appears to be on the order of 100-200 kyr as suggested by the partial presence of the Plummerita hantkeninoides and Micula prinsii biozones, the former of which spans the last $300 \mathrm{kyr}$ of the Maastrichtian (chron 29R below the "K/T boundary"). This hiatus and bioclastic deposits have also been observed at the shallow Saharan platform Selja section near Metlaoui to the south of Ain Settara and are very likely caused by a change in relative sealevel in the latest Maastrichtian.

An interpretation of sea level changes while focusing on a limited interval at the
"K/T boundary" can only be tentative. Sediment response to changes in relative sea level need to be considered as part of a more thorough evaluation of extended Maastrichtian and Danian sections. However, in all three sections visited, most of the upper Maastrichtian marls are high in carbonate content and contain abundant low latitude planktonic organisms typical for open ocean pelagic deposition with a low terrigenous input. Such sediments are expected to be laid down during rises in relative sea level and thus placed in a Transgressive Systems Tract (TST). The minor surface with concentrations of small bivalves at Ain Settara $12 \mathrm{~cm}$ below the top of the carbonate rich marl can be interpreted as a flooding surface, a brief interruption in the overall transgression. A change to more clayey deposition in the uppermost Maastrichtian marks a burrowed surface that could be interpreted as a Maximum Flooding Surface (MFS). This surface is several $\mathrm{cm}$ below the layer with cosmic markers and the sudden extinction of a significant portion of the Cretaceous planktonic foraminifera assemblage but without a real change in lithology.

At Ain Settara several $\mathrm{cm}$ above the layer with cosmic markers is a thin discontinuous unit with a much higher carbonate content and abundant Cretaceous taxa (reworked) referred to as storm deposits or turbidites followed by another thin layer of breccia-like brown clay. These two layers may indicate the distal effect of a relative sea level change and thus indicate a Sequence Boundary (SB) at this position in the earliest Danian. These two thin units and the remainder of the Dark Boundary Clay may be interpreted as lowstand deposits. The return to carbonate-rich deposition indicates the onset of transgressive deposition. The surface separating the Dark Boundary Clay from the overlying carbonate rich deposits is a Transgressive Surface (TS). This interpretation is

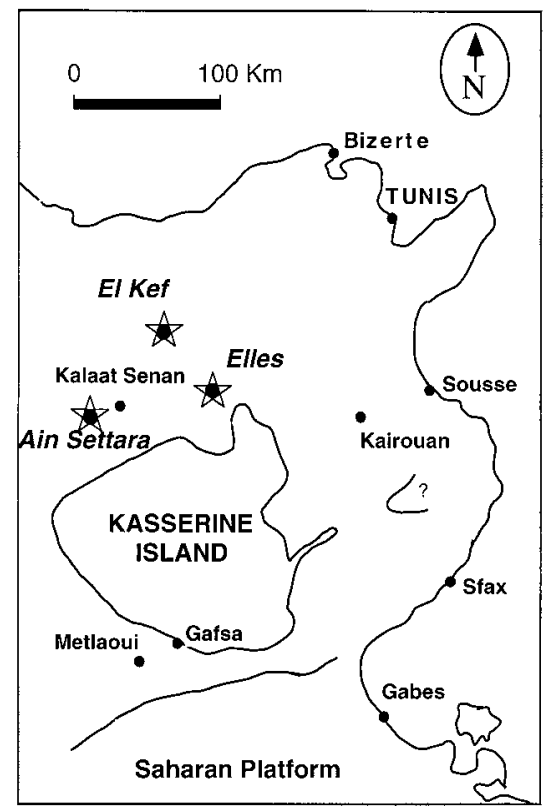

Sketch map showing the palaeogeographic position of the studied section. 
tentative but if upheld it appears that if a cosmic event occurred at the $\mathrm{K} / \mathrm{T}$ boundary the impact took place early in a highstand systems tract.

All together, the Tunisian sections thus provide an excellent and unique paleogeographic transect from shallow to deeper waters, but the El Kef section remains the best GSSP type section. At the El Kef section, it appears that the GSSP is somewhat covered by vegetation. Although the boundary-level can easily be dug up in different places, this is not a satisfactory solution for a GSSP because uncertainty persists as to the exact location of new profiles with regards to the original type-section. This problem will, however, be solved in the near future by the Tunisian Geological Survey which will take the necessary steps for the preservation of the original GSSP locality. In contrast, the Aïn Settara and Elles sections are both situated on the flanks of steep ravines where vegetation cannot form a continuous cover. Outcrop conditions are ideal at both of these sections and they were extensively resampled by workshop participants as well as the Tunisian Geological Survey for their archives and distribution to interested parties.

Considering both the scientific aspects and outcrop conditions, we conclude that there are currently no compelling reasons to replace the El Kef GSSP by another typesection. The main problem of the type-section is the preservation of the site, which will be solved in the near future. Most important for future studies is the fact that the GSSP can be complemented by two other sections at Elles and Aïn Settara. These sections are, however, not quite as complete as the one at El Kef and they can thus not replace the original type-section. But due to their different paleogeographic settings, they provide important additional information about the $\mathrm{K} / \mathrm{P}$ boundary events in continental shelf and upper slope enviroments. We therefore recommend that these two sections be instituted by the Paleogene Subcommission as Auxiliary Stratotype Points (ASPs) for the K/P boundary.

\section{Jürgen Remane}

Univ. de Neuchâtel, Institut de Géologie, 11, rue Emile-Argand, CH 2007 Neuchâtel, Switzerland, e-mail:jurgen.remane@geol.unine.ch

\section{Gerta Keller}

Department of Geosciences, Princeton Univ., Princeton, NJ 08544, USA

e-mail:keller@geo.princeton.edu

\section{Jan Hardenbol}

826, Plainwood Drive, Houston, Texas 77079 ,

USA,e-mail:Jhardenbol@aol.com

M. ben Haj Ali

Office National des Mines 24 Rue 8061-2035, La Chaguia, B.P. 215, 1080 Tunis,Tunisie

\title{
Fifth International Symposium on the Jurassic System
}

\author{
Vancouver, Canada, August 12-15, 1998
}

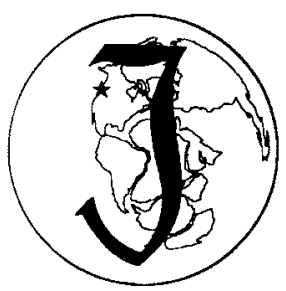

This past summer it was the turn of the Canadian community of Jurassic geologists to host the Fifth International Symposium on the Jurassic System, sponsored by the International Subcommission on Jurassic Stratigraphy and the International Commission on Stratigraphy. Following previous meetings in Erlangen, Lisbon, Poitiers, and Mendoza, the Fifth Symposium was convened on the campus of the University of British Columbia (August 12-25), and with 165 delegates from 26 countries attending, was the largest such gathering to date. The Organising Committee, chaired by Paul Smith, included Russell Hall, Terry Poulton, Howard Tipper, Jim Haggart, David Taylor, Beth Carter, Giselle Jakobs, Steve Irwin, Jozsef Pálfy, and Melanie Butcher. Of particular note, and critical to the success of the meeting, was the invaluable assistance of 6 volunteers from the Vancouver Paleontological Society.

While the primary mandate of the Jurassic Subcommission is stabilizing the Jurassic time scale by designating basal stratotypes of the Jurassic Stages at localities which then become the standard for global correlation, these meetings also serve to bring together specialists investigating all aspects of the Jurassic, and the Vancouver organising committee made special efforts to enhance multidisciplinary aspects of Jurassic studies.

Four days of conference sessions began with a Plenary Session dedicated to Howard Tipper (G.S.C. Vancouver). A humorous and moving tribute by Bob Anderson reviewed Howard's long and productive career investigating Jurassic rocks in western Canada. The four presentations in this Session were intended to introduce delegates to the history of Jurassic studies in western Canada, some of the unique perspectives our Jurassic sequences have provided in understanding accretionary tectonics (Jim Monger), and the implications for mineralisation (Bob Anderson), biostratigraphy (Paul Smith) and biogeography (Martin Aberhan). The contributions from, and interdependence of, many branches of geological research were evident throughout these talks, which also provided a useful regional overview for several of the fieldtrips run in conjunction with the Symposium. An evening lecture on dinosaurs by Bob Bakker, during which he demonstrated his great skills as an artist, a scientific communicator, and an entertainer, was attended by a large crowd of enthusiastic children (with parents and conference delegates swelling the numbers).

In addition to general sessions which gave delegates the opportunity to convey results of their recent research on the paleontology, stratigraphy, and correlation of Jurassic rocks around the world, Special Sessions were devoted to such topics as Extinction and Recovery, Terrestrial Ecosystems, The Hispanic Corridor, Time Scale Calibration, and Sequence Stratigraphy. Posters were on display in the foyer of the conference centre throughout the Symposium, with two late afternoon time slots set aside for viewing and conversations with authors over a beer or two. The Proceedings volume is being prepared for publication by the end of 1999 . Vancouver weather was relatively benign throughout the meeting, and on a warm summer evening delegates particularly enjoyed an outdoor salmon barbeque in the grounds of the spectacular Anthropological Museum overlooking the Pacific Ocean, followed by a

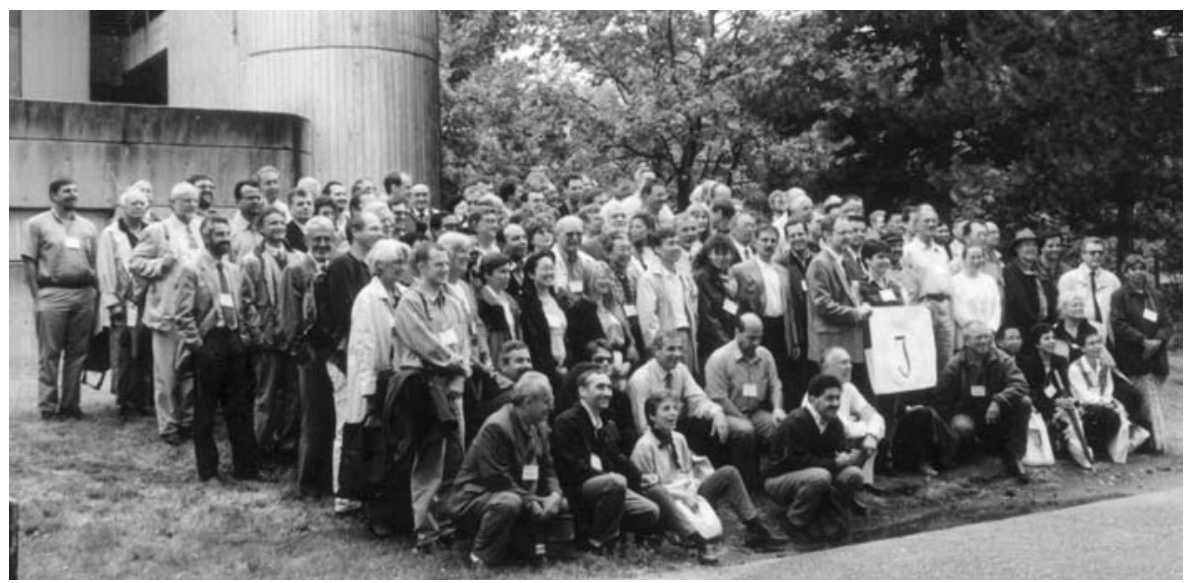

A gathering of delegates on the first morning of the Fifth International Symposium on the Jurassic System. Twenty eight countries were represented. 
wonderful sunset and guided tours of the Museum.

Prior to arriving in Vancouver, many delegates had participated in pre-Symposium field trips. Some had survived the mid-summer heat of Nevada, probably thanks to periodic visits to the famous bar in Luning. David Taylor led this group through several Upper Triassic and Lower Jurassic marine sequences, that at New York Canyon offering good exposures of the Triassic/Jurassic System boundary.

The second of the pre-Symposium fied trips began from Calgary and first visited exposures of the Fernie Formation in the foothills and front ranges of the Rocky Mountains in Alberta. Well displayed here is the transition from stable platform deposits with an easterly, cratonic source in the lower and middle parts of the Formation to the sudden influx in its upper parts of coarse clastics derived from the rising orogen to the west. After a one-day hike to view the Walcott Quarry in the Burgess Shale (Middle Cambrian), this trip then proceeded west along the TransCanada Highway, examining evidence for the accretionary events which contributed to the re-organisation of the Western Canada Sedimentary Basin, beginning in the Late Jurassic. The foreland basin infill sequence resulting from these accretionary events had been seen on the first two days of the trip. The trip was led by Russell Hall, Jim Monger, and Terry Poulton.

One of two post-Symposium fieldtrips traversed the southern Coast Mountains, beginning with a one-day trip to Harrison Lake, and then proceeding northward to Ashcroft, Cache Creek, and Goldbridge. Because of the need on one day to rotate groups of participants by helicopter between three localities north of Goldbridge, the good weather lined up by leader Paul Smith was much appreciated. Exceptional accommodations at a resort with canoes, horses, and swimming, among many other attractions, contributed to an excellent trip. Co-leaders Jim Monger, Terry Poulton and Steve Irwin provided participants with much detail about the structural complexity of the Coast Mountains, and the significance of paleontology in unravelling these structures. The general scarcity of fossils was noted by the non-Canadians, who were impressed by the distances between outcrops, heavy forest cover restricting access, and the tectonic and logistical problems to be overcome by geologists working in the Canadian Cordillera.

Howard Tipper organised the other post-Symposium field- trip, which took participants to the remote Queen Charlotte Islands off the west coast, with their wonderful scenery, Haida cultural attractions, and superb Lower and Middle Jurassic marine sequences. Howard laid on a feast of geological, cultural, culinary, natural history, and travelling experiences which would be difficult to excel, and he was assisted by his wife Esther, Beth Carter, Giselle Jakobs, Jozsef Palfy, Jim Haggart and Russell Hall. Participants particularly enjoyed a day-long trip in zodiacs to tiny Kunga Island, where excellent exposures of Triassic/Jurassic boundary beds were examined, and the remains of an ancient Haida village on nearby Tanu Island were visited. Much marine and terrestrial wildlife was glimpsed along the way.

A guidebook containing detailed descriptions and locality information for all five field trips has been published as a single volume and is available from the Geological Survey of Canada bookstore in Vancouver (at 101-605 Robson Street, Vancouver, British Columbia, Canada V6B 5J3).

Italian colleagues offered to host the Sixth Jurassic Symposium in 2001 and hinted that the most likely location for the meeting and fieldtrips was Sicily. Their offer was accepted by the Subcommission at its final business meeting in Vancouver.

Russell Hall, Terry Poulton, and Paul Smith Earth and Ocean Science, University of British Columbia, Vancouver, BC, V6T 1 Z4 Canada

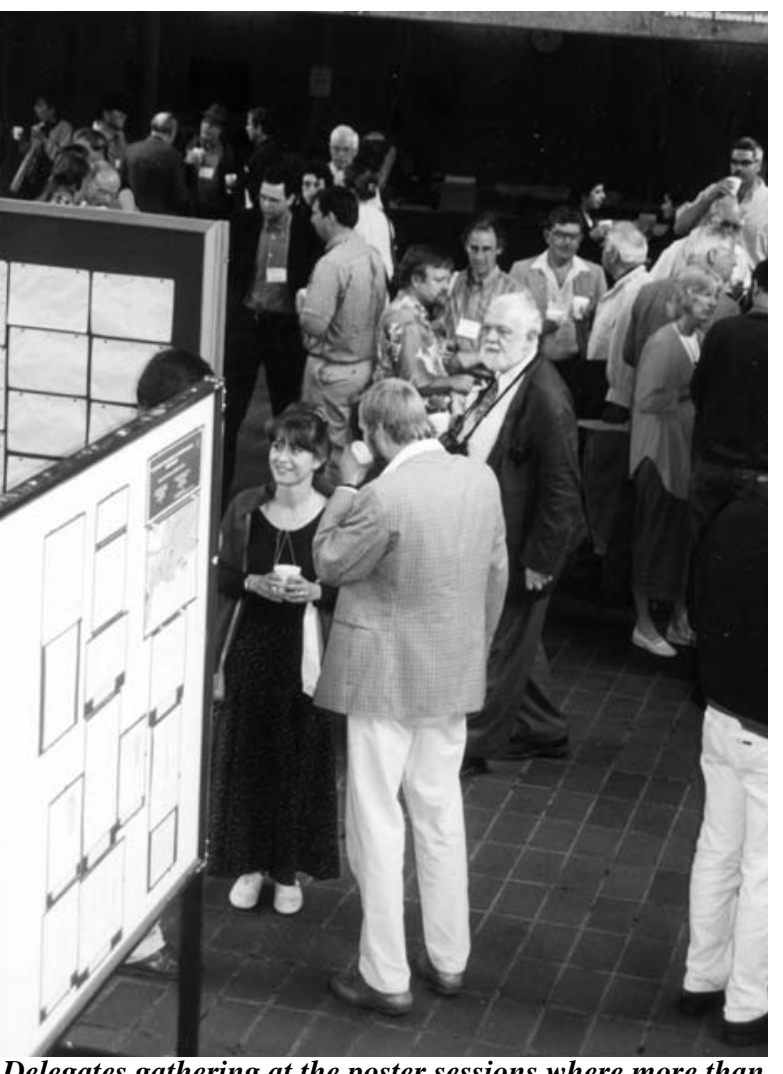
30 posters were presented

\section{International}

conference on the

Central Orogenic Belt of China: Its

\section{structure, composition and evolution}

\section{8-23 October, 1998 \\ Wuhan, China}

The International conference on the Central Orogenic Belt (COB) of China: Its structure, composition and evolution was held at China University of Geosciences, Wuhan, Hubei Province, from 18 to 19 October, 1998, which was followed by a four-day field trip to the Dabie Mountains.

The conference was organized and supported by the China University of Geosciences, the National Nature Science Foundation of China (NSFC) and the International Union of Geological Sciences (IUGS).

The Central Orogenic Belt (COB) consists of the Dabie, Qinling, Qilian and Kunlun Mountains, which constitutes a huge mountain series crossing the whole country from east to west, and extending westwards up to Pamir in central Asia. This belt forms the demarcation line between southern and northern China in terms of geology, climate, geography, environment and biota. Being a region of important mineral resources, water power and biotic diversity, the COB will be one of the major development zones of China in the 21 st century. The conference is designed to exchange the results of studies, such as the composition, structure and dynamic evolution of the $\mathrm{COB}$ and other orogenic belts in the world, the formation and exhumation of the Dabie-Sulu UHP metamorphic belt, recent achievements in the Qinling and Kunlun orogenic belts, and new ideas on evolution of Tethys, so as to contribute to the study of continental dynamics, global change and sustainable development and to help the government in planning future scientific research and making policy for sustainable development in the COB and the Western China. The conference thus attracted wide interest from both China and other countries. A total of 120 participants from 10 countries and region, including Australia, Canada, China, Germany, Hong Kong, Japan, Russia, South Korea, UK and USA, attended the meeting. With 116 abstracts, 36 oral presentations and 25 posters, the two- 
day conference primarily focused on the following three topics:

- composition, structure and dynamic evolution of the COB and other orogenic belts around the world.

- formation and exhumation of high- and ultrahigh-pressure metamorphic belts.

- mineral and fossil fuel resources, environments and sustained development of the area related with the COB.

Dr. Robin Brett, President of IUGS, Prof. W.S. Fyfe, Past President of IUGS, Prof. Hongfu Yin, President of China University of Geosciences (Wuhan), Prof. Harry Green, Vice President of University of California at Riverside, Prof. Ziqing Xu, Vicedirector of Chinese Academy of Geological Sciences, Profs. Hongzhen Wang, A.A. Marakushev, Shutong $\mathrm{Xu}$ and Xuecheng Yuan as well as Dr. Qingren Meng made keynote speeches at the meeting. Prof. Hongfu Yin presented evidence for non-Wil son cycle of tectonic evolution of the $\mathrm{COB}$, including archipelagic rather than 'clean' ocean at the ocean forming stage, soft collision rather than hard-on-hard collision at the collision stage and consequently multicyclicity in orogeny. Robin Brett discussed new opportunities and new challenges for national geological surveys. Ziqing Xu introduced geological backgrounds and scientific objectives for the Chinese first scientific drilling in the Dabie-Sulu UHP metamorphic belt. H. Green presented experimental results for conditions for dissolution and precipitation of $\mathrm{TiO}_{2}$ in olivine, which supports the hypothesis that pressures in excess of $10 \mathrm{GPa}$ are necessary to explain the solubility

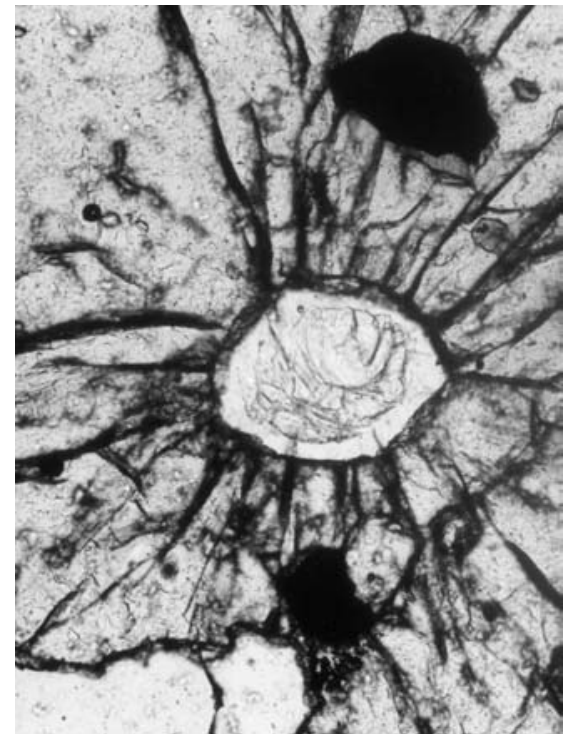

Coesite in eclogite at Shuanghe, Dabie, collected during the field trip.

implied by the $\mathrm{FeTiO}_{2}$ precipitates in the Alpe Arami massif. Hongzhen Wang discussed the formation and evolution of the COB under the overall context of Asia. W.S. Fyfe emphasized the need for new technology and holistic planning for future mining operations to reduce environmental pollution.

During the following 4-day field excursion in the Dabie Mountains, the participants investigated the famous Bixiling coesitebearing eclogite-garnet peridotite complex of about $1.5 \mathrm{~km}^{2}$ in outcrop, the Shuanghe HP slab consisting of coesite-bearing eclogite, retrograded eclogite, UHP garnet-biotite gneiss, marble with or without eclogite nodules or boudins, jadeite quartzite, and amphibolite, the Maowu pyroxenite-eclogite body, the Wumiao eclogite and surrounding quartzofeldspathic gneiss, and the Xidian microdiamond-bearing eclogite in marble. The field trip gave the participants an outline of structure and rock associations of the Dabie UHP metamorphic belt and also a view of scenery in the countryside and Chinese rural life.

Areas for future studies were suggested as follows:

- national geological surveys: New opportunities and new challenges.

- evolution of the $\mathrm{COB}$ and their environmental effects.

- mechanism of formation and exhumation of the Dabie UHP metamorphic belt and implications for continental dynamics.

- structure and composition of crust and mantle in orogenic belts.

- geochemistry and geochronology of UHP rocks.

- geophysical studies of deep lithosphere of the COB.

- high-pressure and high-temperature experimental studies on formation of UHP rocks.

- structure of continental crust and scientific drilling.

Shan Gao and Zhenming Jin

Faculty of Earth Sciences, China University of Geosciences, Wuhan 430074, China

seminated in mid-1997 and in which the directors of African Geological Surveys were asked about their opinion as to the relevance of ten selected topics. The answers to this questionnaire served as a basis for defining priorities for the program and for asking speakers for contributions.

An important aspect of this meeting was to have African geologists express their own views instead of offering them "blueprints of the industrialized countries" as Prof. Wellmer, president of BGR, stated in his speech, because "Africa comprises 53 different nations and these need 53 different solutions".

The Geological Surveys of Angola, Benin, Botswana, Burundi, Cameroon, Ethiopia, Ghana, Ivory Coast, Kenya, Madagascar, Malawi, Morocco, Mozambique, Namibia, Niger, Zambia, Senegal, South Africa, Tanzania and Zimbabwe had sent their representatives; together with keynote speakers from the World Bank, UNESCO, IUGS as well as representatives of the Geological Surveys of Germany, Finland, France, Morocco and The Netherlands. They discussed issues related to the mandate, to the transfer of know-how and technology, to cross-border cooperation and to 1998 in Harare, Zimbabwe. Dr. Hirdes, the 
the exchange and networking of data and information.

The symposium was complemented by a workshop in which the African representatives discussed the strength and weakness of their organizations and elaborated an action plan as a basis for the future orientation of Geological Surveys in Africa. The African geologists pointed out that not even half of the African continent has been systematically investigated for its resource potential so far and that the economic and social development of Africa still lags behind that of most other countries in the world. In order to allow Geological Surveys to provide their contribution to the solution of the socio-economic and ecological issues of the future the following main points were entered into the action plan:

- Definition of the mandate (Geological Surveys as the national advisory institutions in the geosciences sector; recognition of their changed role with respect to a better satisfaction of basic needs);

- Development of strategies (definition of core tasks which address the new challenges with respect to the satisfaction of basic needs and the economic requirements);

- Budget planning (setting up work programmes which are compatible with the financial resources; looking for possibilities of external funding);

- Geoscientific information (elaboration of user-oriented data and recommendations, creation of understanding for geosciences as a "product");

- Public relations (promotion of public understanding and appreciation for the contributions which the geosector is able to provide for the sustainable and environmentally compatible use of natural resources);

- Formation and training (setting up plans for human resources development as a basis for the building of capacities which are compatible with requirements);

- Infrastructure (purpose-designed strengthening of the technical infrastructure with special regard to internationally compatible computer-based information technology).

According to the opinion of all participants the symposium achieved its goal, namely to elaborate-by a continent-wide dialogue among equal partners-recommendations which will serve as a basis for describing future-oriented tasks for the individual Geological Surveys. The participants from Africa and from the industrialized countries present at Harare pointed out that, through this symposium, for the first time geologists from all over Africa could be brought together to discuss their future tasks and to formulate an action plan reflecting the regional and local views and experience of African geologists.

The participants of the symposium expressed their hope that the action plan which they had elaborated jointly may be realized in a constructive manner in their home countries enabling Geological Surveys to fulfil their responsibilities for the basic needs and the welfare of people in Africa.

Dr. Georg Andritzky and Dr.Ulrich Ranke International Cooperation Section Federal Institute for Geosciences and Natural Resources, P.O.Box 510153,D 30631 Hannover, Germany

\section{Natural hazards, society and cultural heritage: Approaches for the next millenium}

\section{The 1999 Tokyo Appeal}

The UNESCO-IUGS-IGCP Symposium on Natural Hazards and Cultural Heritage (Tokyo, 30 November-1 December 1998) was organized by the IGCP National Committee of Japan, the Landslide Research Council of Japan, Kyoto University, the Canada-Japan Science and Technology Agreement Groups, the IGCP-425 Project Team "Landslide Hazard Assessment and Cultural Heritage and Other Sites of High Societal Value" and the IGCP-383 Project Team "Natural Disasters in the West Pacific and Asia", with the co-sponsorships of the Technical Committee on Landslides (TC11) of the International Society for Soil Mechanics and Geotechnical Engineering (ISSMGE), Commission No. 2 "Landslides and Other Mass Movements" and Commission No.16 "Engineering Geology and Protection of Ancient Monuments and Archaeological Sites" of the International Association of Engineering and the Environment (IAEG), Division 8 "Forest Environment" of the International Union of Forestry Research Organizations, the Japan Landslide Society, the Japan Society of Erosion Control Engineering, the Japan Society of Engineering Geology, the Geological Society of Japan, the Japanese Geomorphological Union, the ISSMGE Asian Regional Technical Committee "Protection of Cultural Heritage from Landslides" (ATC-9), the Geological Survey of Japan, and the IUGS Commission COGEOENVIRONMENT (Prof. K. Sassa was the coordinator).

The following appeal was launched from the experts that participated in the Symposium:

We, as international experts in the earth sciences, are concerned at the deterioration of many of the world's cultural heritage sites under the threat of both natural and manenhanced hazards.
In consideration of the richness and global diversity of this heritage, and the integral place it occupies in the cultures of all the nations of the world, we

1. recognize that protection of the cultural heritage is vital to any balanced socioeconomic development;

2. recognize the fundamental role that understanding of natural and human-induced environmental change is bound to play in the achievement of any degree of sustainable development;

3. consider that both natural and humaninduces change should be accommodated and managed by monitoring a wide range of earth-surface changes because of the important insight such changes provide in the anticipation and prognosis of future changes;

4. consider that today's environmental and developmental concerns demand the application of the latest and best scientific

research in order to define problems, identify causes and effects, provide sound solutions, and design cost-effective remedial measures.

In the light of these considerations, the earth sciences and cultural heritage communities urge:

5. that the contribution of the geosciences to the measurement and understanding of global changes, natural and humaninduced hazards, and the impact these hazards have upon the delicate balance between natural environment, cultural heritage and human settlements be recognized and enhanced;

6. that all concerned (the general public, policy-makers and national and international funding agencies) should be aware of the importance of the earth sciences in both underpinning sustainable development and the mitigation of natural and human-induced hazards;

7. that deliberate efforts be made to narrow the gap between developing and advanced countries in the understanding, management and monitoring of deteriorating heritage sites means of international collaboration, as exemplified by the current range of projects and programs under the aegis of organizations such as the International Geological Program; and

8. the national and international expertise in these fields be focused and mobilized for the protection of the world's threatened heritage sites with the aid of better-targeted technical and financial support and enhanced international communication and collaboration.

\section{Paul Marinos}

National Technical University of Athens, 42, Patission St., 10682 Athens, Greece 